\title{
Strategies to improve university's governing ability based on the organizational structure
}

\author{
Lin lin \\ Institute for Higher Education, \\ Jilin Agricultural University, \\ Changchun, China \\ linlinjlau@126.com
}

Keyword: university’s governing ability; organization structure; strategy

\begin{abstract}
From the perspective of organizational structure, this paper analyzes problems existing in the vertical direction, the horizontal direction and the general direction, and puts forward specific strategies to improve university's governing ability in four aspects, namely straightening out the power structure relationship, adjusting the responsibility and power distribution, optimizing the organizational structure and simplifying the structure.

UN Global Governance Committee once gave an authoritative definition of "governance" in the 1990s: "Governance" refers to the joint management of affairs by individuals or private or public institutions. With governance, different conflicts or interests can be reconciled, and it is a continuous process that joint actions are adopted ${ }^{[1]}$. In terms of "university governance," papers in ASHE series books discussing university students' governance in the 21st century defines them as "the structure and process for stakeholders inside and outside universities to participate in the decision-making of major university affairs." [2] Of course, internal and external university governance is different. This paper mainly studies universities' internal governance. University organizational structure is a structure relationship featuring both labor distribution and cooperation among the work of university members, which is mainly reflected as duties, responsibilities, power, et al. It decides the labor distribution and coordination method of education, teaching, scientific research and other missions, and decides the operation status of the internal management model, academic power and administrative power.
\end{abstract}

\section{Introduction}

The construction of internal university governing structure is to ensure the coordinated operation of universities and strike a balance among rights of various aspects. In the internal university governing structure, power structure relationship is at the core. The organizational structure built based on the power structure relationship is the basis, and the institutional system is the prerequisite and guarantee ${ }^{[3]}$. Among them, power configuration influences the construction and choice of the organizational structure, and the organizational structure is the ultimate reflection of the power distribution. Of the three factors, the organizational structure plays the role of a connecting link. Therefore, the optimization of the university's organizational structure can greatly enhance the university's internal governing structure construction and improve the university's governing ability.

\section{Problems existing in the university's organizational structure}

A. Generalized administrative powers, weakened academic powers and serious administerization phenomenon in the horizontal direction

In the current university organizations, the administrative power is superior to the academic 
power; the former replaces or interferes with the latter; the responsibilities and duties of the administrative power institutions are not clearly-divided, thus these administrative power institutions shuffle their responsibilities and duties, resulting in nonfeasance of administrative powers. Under the situation, the administrative power of the whole university is generalized, and the academic power is weakened. University students and academic organizations have gradually been reduced to slaves of implementing administrative powers under the high pressure of the administrative power, thus losing their independence to pursue academic study, and finally causing the derivation of the academic value in the university. The university's administrative power drifts away from education, teaching and academic study, leading to crises of university students' existence legitimacy.

\section{B. Irrational distribution of powers and responsibilities in universities and colleges and floating of the management focus in the vertical direction}

Distribution of responsibilities and rights is a core element of the organizational structure. After the college system reform of Chinese universities, university organizations mainly adopt the university-college-department three-level structure, and the university-level management model dominates. In other words, the university level still masters most resources, including funds distribution, scientific research application, appraisal honors, major setting, teaching resources distribution, etc. However, the college-level and the department-level of universities are in full charge of students' enrolment and cultivation, educational and teaching practices. As a result, the university level has overwhelming power, while the college and department level is in an extremely weak position. The asymmetry of powers and responsibilities between the university level and the college and department level leads to the floating of the management focus. Worse still, the bases to formulate policies and make decisions lose their validity, thus influencing the improvement of the whole university's governing ability.

\section{Differentiation of university organizations, clumsy structure and lack of integration in the integrated direction}

With the updating and development of university functions, functions of university organizations have become increasingly complex. The institutional setting of university organizations gradually coincide with that of the government organs. Based on the original teaching system and scientific research system, university organizations have increased the management system, the logistics system and a series of subsidiary service systems and other departments and institutions. These departments and institutions are either independent or affiliated to the original

institutions or operating jointly ${ }^{[4]}$. They keep on expanding the boundary and scope of the university's organizational structure, increasing its complexity. Consequently, university's organizational structure is too complex. The large number of institutions and personnel force universities to undertake responsibilities of many governments and society. On the other hand, different systems play a different role in university organizations. Their working modes, concepts and value orientation are quite different. In this way, the current university's organizational structure is too complex, and hard to manage and lacks integration ${ }^{[5]}$.

\section{Strategies to improve university's governing ability from the perspective of optimization}

Concerning problems existing in the university's organizational structure in China and to achieve an overall improvement of Chinese university's governing ability, the author puts forward specific strategies in the following aspects:

\section{A. Straighten out the power structure relationship and establishment the dominance of the academic power}

First, the administrative power and the academic power within universities should be straightened out; the administrative and academic relationship should be clearly defined; the academic power should not rely too much on the academic power; and the powers of administrative 
organizations should be clearly-divided. Second, in terms of management, the original system should be reformed with new management ideas introduced. In the institutional setting, academic affairs and administrative affairs should be distinguished and clearly defined. Departments and units engaged in the academic work, including teaching and scientific research institutions, should be listed as the academic departments; while departments and units engaged in personnel, financial, logistics and asset management, should be listed as the administrative departments. The two should be separated from each other expressly, with their responsibilities and duties clearly distributed. At the same time, the academic departments should have more academic political powers, and the academic powers of the original administrative department should be totally separated out to improve the institutional operation efficiency.

\section{B. Adjust the distribution of responsibilities and rights and implement the academic management right}

In the current three-level management structure, the university level dominates the management right of the whole university, and most decision-making right and rare resources. However, responsibilities and duties of educational and teaching practices are in the charge of colleges and departments. Due to derivation from teaching, talent cultivation, school policies or decision-making, a series of problems including invalidity of policies are popping up. In the three-level university structure relationship, college is in the middle, which plays the role of a connecting link. It has the most understanding of educational teaching and talent cultivation. Therefore, it is necessary to establish the principle of the college management and the university leaders at the core. The university level should focus on the general guidelines and policies and take the responsibility of the overall administrative and academic policies and overall development plans. Under the leadership of the university level, departments should act as management institutions of academic activities, including teaching and scientific research, according to the college and subject characteristics, to achieve self-management and self-development, and promote the initiative and creativity of college teaching and scientific research.

\section{Optimize the organizational structure and establish the matrix-type organizational structure}

Currently, universities should adopt scientific research projects as the bond to establish a diversified and interdisciplinary team, and build a series of flexible scientific research grassroots organizations, straightening out the relationship among colleges, departments and scientific research institutions, further enhance the innovation, integration and cohesion ability of scientific research organizations, and gradually put in place a diversified, flexible, opening and sharing innovational scientific research system ${ }^{[6]}$. It is necessary to give full play to the role of teaching organizations and teams, break through the college and department barriers and build teaching organizations featuring coordinated development and mutual promotion. Besides, the management system should be improved; teachers should be managed differently and encouraged to conduct teaching activities; different positions should be set up according to different titles of teachers so as to give full play to the teaching-type and the research-type teachers, and to finally achieve the intersection and cooperation between he administrative departments and the academic research institutions, teaching and scientific research institutions, stimulate the innovation ability and vigor of the whole university organizational structure and promote optimization of the university organizational structure.

\section{Develop a correct understanding of the fundamental functions of universities and realize the flattening of university's organizational structure}

The swelling of university's organizational structures and functions, and the excessive number of administrative personnel have influenced the development of Chinese universities. Universities are expected to fulfil more functions, but are deviated from their basic functions. Therefore, the current university organizations should return to their original purpose, separate out subsidiary functions developed over the past years, simplify their subsidiary organizational structures, explore and realize the marketization and social operation of these organizations and institutions, devote limited resources to the innovation of university teaching, scientific research and development. The 
university's organizational structure should also expand its organizational management scope, reduce the management levels and achieve the flattening of the organizational structure.

\section{References}

[1] UN Global Governance Committee. Our Global Partnership[M]. Oxford: Oxford University Press, 1995, 23.

[2] GAYLE,DENNIS JOHN.Tewarie,Bhecndradatt Gov-emence in theTwenty-First-Century University.Ap—proaches to Effective Leadership and Strategic Management[M].ERIC Dides ED482560.

[3] YAO Chengjun. An exploring and discussion of the internal governing structure in Chinese universities from the perspective of characteristics of university organizations[J]. Educational Journal of Renmin University of China, 2012 (04), 60-67.

[4] JIN Xiangbing \& MIN Weifang. A study on the differentiation and integration of university organizations[J]. Higher Education Research, 2004 (01), 32-38.

[5] JIN Xiangbing \& MIN Weifang. A study on the differentiation and integration of university organizations[J]. Higher Education Research, 2004 (01), 32-38.

[6] ZHANG Xiaying. Research into optimization of the high-level research-style university organizational structure and management[D]. Zhejiang: Zhejiang University, 2007, 83-87. 